\title{
TPACK + MATHEMATICS: A REVIEW OF CURRENT TPACK LITERATURE
}

\author{
Karlee Stapf \& Barbara Martin \\ Southern Illinois University Edwardsville (SIUE), USA
}

\begin{abstract}
This paper will summarize a review of current literature on the Technology, Pedagogy and Content Knowledge (TPACK) framework, discuss innovative technology integration in teacher preparation and mathematics methods courses for teacher candidates studying elementary education. Themes that emerged in the review of current TPaCKliterature included the importance of understanding the TPACK framework, developing self efficacy, the vital role that modeling plays, how collaboration impacts and finally, just how powerful reflection can be in the application of TPACK. This paper will examine and explain these different themes and summarize the current literature as well as highlight trends on technology integration and TPACK.
\end{abstract}

\section{KEYWORDS}

Technology integration, innovation, elementary education, math methods, TPACK, teacher preparation.

\section{INTRODUCTION}

Technology has been gradually infused into the everyday lives of students and educators across the country. In response to this, technology integration has become a goal and vital part of teacher education programs across the country. Despite the fact that today's teacher candidates are technologically fluent with everyday technologies; such as, cell phones, laptops and the Internet, many teachers in training still struggle with how to successfully implement technology into instruction. Technology in the classroom by itself can not successfully help students learn, it depends on how that technology is used, and professors today are eager to help pre-service teachers develop those skills.

To fully understand how to successfully integrate technology into teacher preparation programs, researchers often rely on the Technological Pedagogical and Content Knowledge (TPACK) framework. The TPACK framework is used at all instructional levels to help teachers align their pedagogy with technology and content in the learning environment. For pre-service teachers to fully develop TPACK, each of the constructs need to be addressed and thoughtfully integrated into instruction. For example, educators will need to intentionally address technological knowledge (TK), content knowledge (CK), and pedagogical knowledge (PK) throughout their lessons. Also, teachers need to be able to seamlessly use technology and pedagogy together in a way which strengthens both constructs. Lastly, the technological content knowledge (TCK), pedagogical content knowledge (PCK), and technological pedagogical knowledge (TPK) constructs should be thoughtfully addressed. Once educators have proactively planned for these constructs in their teaching, they can then unite them into TPACK.

In order to better understand successful technology integration in teacher preparation courses, we reviewed all of the current research on TPACK in Elementary Math Classrooms. The following themes emerged and will be further explained in the rest of the article: understanding TPACK, 
International Journal on Integrating Technology in Education (IJITE) Vol.8, No.3, September 2019

developing TPACK, and incorporating TPACK in math methods courses. This article will review each of these themes.

\section{UNDERSTANDING TPACK}

In order to start developing TPACK into future classrooms, it is critical to fully understand what TPACK is so the authors' have dedicated this section of the paper to building a basic understanding of the framework. Technology knowledge (TK) is human knowledge which involves tools, materials, and systems. Pedagogical knowledge (PK) is the process and practices or methods of teaching. Content knowledge (CK) is a special combination of content and pedagogy that is uniquely constructed by teachers; for example, when students are learning elementary math concepts by demonstrating skills such as addition, subtraction, multiplication, division, measurement or shape recognition. TPACK originated from Schumer's (1999) framework that examined the overlap of content and pedagogy. As technology evolved, the framework further developed to include pedagogy, technology, and content (Koehler, Mishra, Cain, 2013). TPACK occurs at the center where all three of these separate areas of knowledge overlap.

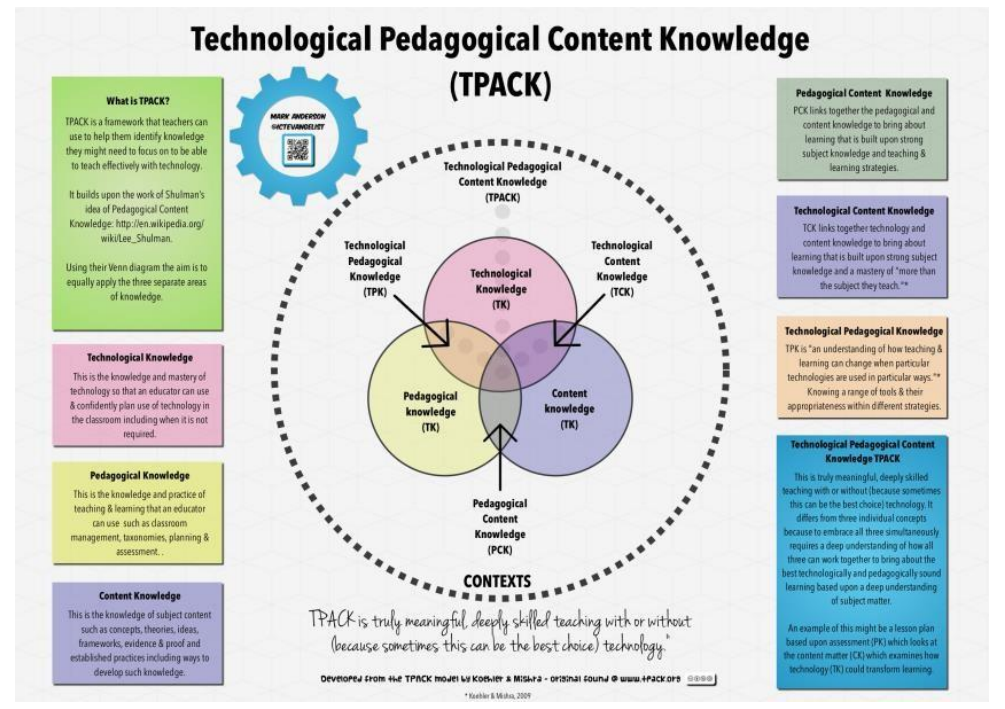

Figure 1: Technological Pedagogical Content Knowledge Framework (Koehler \& Mishra, 2009)

TPACK is being able to know the content specific material and how to use infuse technology into the content using the best teaching practices. Teachers not only need to know how to work the technology that they have but how to infuse it into the curriculum and teach using research-based instructional strategies. Successfully incorporating technology into mathematics requires the teachers to know how that specific piece of technology can fit in with the curriculum that is being taught. Not only do the teachers need to have a handle on that specific content of the curriculum, but also need to be able to teach their students how to use the technology properly. Strategically chosen technologies paired with mathematical concepts can assist students in engaging and understanding often difficult or abstract mathematical content.

\section{Literature ReVIEW Theme ONE: DeVEloping TPACK}

Once TPACK is fully understood, developing these different areas of knowledge is the subsequent action. Through a review of current literature on TPACK in teacher preparation, one of the common themes that surfaced was the development of TPACK. For example, researchers 
International Journal on Integrating Technology in Education (IJITE) Vol.8, No.3, September 2019

have said when pre-service teachers are exposed to TPACK, they showed greater gains in technology integration (Wetzel, Buss, Foulger, \& Lindsey 2014; Finger, Glenn, JamiesonProctor, Romina, Cavanagh, Rob and Albion, Peter and Grimbeek, Peter and Bond, Trevor and Fitzgerald, Robert and Romeo, Geoff and Lloyd, Margaret 2013; Hsu 2012; Bate, Day, Macnish 2013; Keser, Yilmaz, F., Yilmaz, R. 2015; Mouza, Karchmer-Klein, Nandakumar, Ozden, Hu, 2014; Tondeur, van Braak, Sang, Voogt, Fisser, Ottenbreit-Leftwich, 2012). In specific recent study, researchers examined two groups of pre-service teachers, one group was exposed to TPACK while the other was not (Caro \& Harvey, 2016). The outcome showed that the students exposed showed greater strengths in technology integration than their peers who have not heard of this framework. This illustrates the importance of TPACK early on in the curriculum through multiple vehicles such as a math methods class and a technology-intensive class. For example, in another recent research article, researchers found that pre-service teacher's involvement in technology-enhanced lessons or courses were the main way they developed their TPACK (Yigit, 2014).

Preservice teacher preparation courses that focus on TPACK are a great start to understanding and developing this framework, however current research on TPACK found that teacher candidates also need to have more teaching opportunities to sharpen their skills in planning technology integration (Mudzimiri, 2012). Providing additional opportunities would give preservice teachers the chance to practice and further develop their understanding of TPACK and build confidence. Pre-service teachers have a hard time applying what they had learned in the courses in the way they want to (Wetzel, Buss, Foulger, Lindsey, 2014; Mudzimiri, 2012). Presenting and teaching a concept in front of a classroom of children is a lot more taxing than sitting in a college classroom and listening to a lecture; therefore, it is highly important that preservice teachers are not only taking classes about TPACK, but they are also incorporating this knowledge in their instructional experiences. These teaching opportunities will give students more time to practice applying skills in the classroom setting which could lead to better planning, smoother deliver and a positive impact on their future students.

In one study (Yurdakul, 2018) researchers were able to collect data from 1,493 pre-service teachers. These researchers used two instruments to assist them in collecting the data they needed and found that digital nativity, or the recent generations born using digit technology, is a significant predictor of TPACK competency. This research showed the importance of integrating TPACK into teacher preparation courses, particularly for those pre-service teachers preparing to teach in today's ever-changing educational environments.

Another common theme presented in the TPACK current research was the connection of TPACK to development of teacher candidate self-efficacy, or one's belief in one's ability to succeed in specific situations. Self-efficacy and TPACK have a direct relationship on one another, meaning when one increases it causes the other one to improve as well. For example, when self-efficacy is increased in a pre-service teacher, TPACK increases; and when a student further develops TPACK, their belief in themselves to succeed with teaching amplifies (Keser, Yilmaz, F., \& Yilmaz, R. 2015; Joo, Park, \& Lim, 2018). When TPACK and self-efficacy are cultivated, this makes pre-service teachers perceive technology with ease and usefulness (Joo, Park, \& Lim, 2018). Self-efficacy skills can be developed by having preservice teachers take more educational technology courses, methods courses, lesson planning, and attain more field experience (Lee, Y., \& Lee, J. 2014). This increase in coursework helps students feel more confident and supported, allowing them to take risks and try new innovative technologies in their future classrooms. An article concludes that senior students showed a significant growth from the freshman students among their TPACK competencies and self-efficacy perception levels toward technology integration from their field knowledge education and courses (Keser, Yilmaz, F., \& Yilmaz, R. 2015). 
International Journal on Integrating Technology in Education (IJITE) Vol.8, No.3, September 2019

\section{Literature Theme Two: InCORPORATING TPACK IN MATH MeTHOdS COURSES}

In an effort to further refine the literature review, the authors' applied the specific search criteria necessary for finding current research on TPACK specially in the math methods courses that teacher candidates take in teacher preparation program. To help incorporate TPACK into a Math Methods courses, TPACK standards need to be outlined and technology should be integrated into math specific lessons and activities. Several research studies supported the idea that Information and Communication Technology (ICT) integration in teacher preparation math methods courses can help pre-service teachers prepare students for our digital era (Yigit, 2014; Bate, Day, Macnish, 2013 Tondeur, et. al. 2011; Choe, \& Lee 2015). Giving students the ability to see what is expected of them allows students and embodies Niess' five stage developmental process in integrating ICT into mathematics. Niess' five stages include: recognizing, accepting, adapting, exploring, and advancing (Kinuthia, Brantley-Dias, \&Junor Clarke, 2010; Leeman, 2013; Polly, 2014).

After recognizing what the expectations for TPACK in mathematics are, pre-service teachers can start envisioning how this would look in their own classroom. To help pre-service teachers have accepting attitudes for technology in the classroom, recent research suggests that math methods courses should tie in the Concrete, Representational, and Abstract (C-R-A) learning design. The C-R-A learning design significantly enhances pre-services teachers' knowledge and use of TPACK (Bate, Day, \&Macnish, 2013). This research proved that learning with manipulatives (concrete), working mathematically with data (representational), and the use of computer simulations to build alternative scenarios (abstract), can promote pre-service teachers connection with mathematics that could not have been acquired within a traditional classroom setting (Bate, Day, \&Macnish, 2013).

Another theme that emerged through the review of current literature on TPACK was the important of teacher educators as role models for pre-service teachers (Tondeur, van Braak, Sang, Voogt, Fisser, \&Ottenbreit-Leftwich, 2012). Having role models can help pre-service teachers further develop their passion, interest and knowledge towards successful integration of TPACK techniques into their own future classroom (Lunenberg, M. Lunenberg K., Anja F. \& Anja S., 2007). Positive role models are also linked to self-efficacy; therefore, the more role models we have for new educators, the more self-efficacy they will develop which also increases the amount of TPACK being developed (Keser, Yilmaz, F., \& Yilmaz, R. 2015). Thirdly, modeling can also enhance pre-service teacher's understanding of TPACK by helping them to expand their pedagogical repertoire, to reflect on their own teaching, and to rethink the connection between the theory and the practice of teacher education (Lunenberg, M. Lunenberg K., Anja F. \& Anja S., 2007). Future educators, while modeling and observing other classrooms are able to then adapt and modify instructional ideas to fit their own classroom, while incorporating the third stage of Niess's developmental process.

Collaborating with peers is another concept that was prevalent in the current research on TPACK in teacher preparation. Research found that a collaborative relationship can help support preservice teachers develop TPACK by engaging students in communication, collaboration and inquiry-oriented technologies (Niess, 2018). This type of knowledge-building community describes a dynamic interaction of key tools and instructional processes for scaffolding the content towards an enhanced TPACK understanding (Niess, 2018). Collaborating with other preservice teachers allows them to also experience the exploring stage of Niess's developmental process. Future teachers are able to share and brainstorm original ideas all while being supported in this collaborative group setting. 


\section{LiterATURE REVIEW THEME THREE: IMPORTANCE OF REFLECTION}

The last theme that arose from the review of current research on TPACK was the importance of reflection. Reflection is a vital skill in a collegiate course and allows students to develop a deeper sense of understanding, in this case, about the role of technology in the classroom. Research by Mouza and Karchmer-Klein (2013) concludes that case development, projects, that allow preservice teachers to reflect on their work have the potential to connect the dots that create TPACK. The goal of the study was to bring together all the knowledge gained in separate courses into one cohesive context, in turn, developing TPACK knowledge in pre-service teachers (Mouza \&Karchmer-Klein 2013). Reflection also allows pre-service teachers to develop the last stage in Niess' developmental process: advancing. People who reflect on the process itself are able to do that task more effectively the next time because they identify what can be improved and how to make those changes. Reflection allows pre-service teachers to work on their metacognition, think about what they are learning and helps to develop even more successful strategies for future integration.

\section{CONCLUSiON}

In order for today's classrooms to adapt to the changing times, teacher preparation programs have a responsibility to be dedicated to providing application of current research trends. This review of literature closely examined the themes that are surfacing in successful technology integration through the use of the TPACK framework. In 2006, Mishra and Koehler presented research to support that technological, pedagogical, and content knowledge can lead to a deeper and more meaningful learning in the classroom (Koehler \& Mishra, 2009). Through this review of current TPACK literature, the authors have found that research in this area is growing to help better understand how to better achieve the rich overlap of the TPACK constructs. Themes that emerged in the review of current literature include the importance of understanding the TPACK framework, developing self efficacy, the vital role that modeling plays, how collaboration impacts and finally, just how powerful reflection can be in the application of TPACK.

Technology in the classroom gives students more freedom to be creative and use different platforms to take control of their own education. This technology can not come at the cost of pedagogy or content. In order to continue our future classrooms to grow, successful technology integration is vital. Using the TPACK framework in teacher preparation programs can help teacher candidates become more innovative in and outside of the classroom and begin to envision themselves as future role models for other educators and students.

\section{REFERENCES}

[1] Anderson, M. (2013, May 28). Technological, Pedagogical and Content Knowledge. Retrieved February 18, 2019, from https://ictevangelist.com/technological-pedagogical-and-contentknowledge/

[2] Angeli, C., \&Valanides, N. (2009). Epistemological and methodological issues for the conceptualization, development, and assessment of ICT-TPCK: Advances in technological pedagogical content knowledge (TPCK). Computers \& Education, 52(1), 154-168.

[3] Bate, F., Day, L. and Macnish, J. (2013). Conceptualizing Changes to Pre-Service Teachers' Knowledge of how to Best Facilitate Learning in Mathematics: A TPACK Inspired Initiative. Australian Journal of Teacher Education, Volume 38, Issue 5, 13-30. Retrieved from:https://files.eric.ed.gov/fulltext/EJ1014049.pdf

[4] Caro, R. \& Harvey, D. (2016). Developing Preservice Teachers Technology Integration skills using TPACK. In G. Chamblee \& L. Langub (Eds.), Proceedings of Society for Information 
Technology \& Teacher Education International Conference 2016 (pp. 2796-2801). Chesapeake, VA: Association, for the Advancement of Computing in Education (AACE). Retrieved January 27, 2017

[5] Choe, H., \& Lee, T. (2015). Implementation and Analysis about Technology Knowledge Education Program for Pre-service Teacher based on the TPACK Model. Journal of the Korea Society of Computer and Information, 20(2), 231-239.

[6] Finger, Glenn and Jamieson-Proctor, Romina and Cavanagh, Rob and Albion, Peter and Grimbeek, Peter and Bond, Trevor and Fitzgerald, Robert and Romeo, Geoff and Lloyd, Margaret. (2013). Teaching teachers for the future (TTF) project TPACK survey: Summary of the key findings. Australian Educational Computing. 27 (3), 13-25. Retrieved from:https://espace.curtin.edu.au/handle/20.500.11937/2712

[7] Finger, Jamieson-Proctor, Cavanagh, Albion, Grimbeek, Bond, Fitzgerald, Romeo, and Lloyd (2013). Teaching teachers for the future (TTF) project TPACK survey: Summary of the key findings. Australian Educational Computing. 27 (3), 13-25. Retrieved from:https://espace.curtin.edu.au/handle/20.500.11937/2712

[8] Hsu, P. (2012). Examining the impact of educational technology courses on pre-service teachers' development of technological pedagogical content knowledge. Teaching Education, 23(2), 195-213.

[9] KabakciYurdakul, I., \&Çoklar, A. N. (2014). Modeling preservice teachers' TPACK competencies based on ICT usage. Journal of Computer Assisted Learning, 30(4), 363-376.

[10] Keser, H., Yilmaz, F., and Yilmaz, R. (2015). TPACK Competencies and Technology Integration Self-Efficacy Perceptions of Pre-Service Teachers. Elementary Education Online, 14(4), 1193-1207.

[11] Kinuthia, W., Brantley-Dias, L. \&Junor Clarke, P.A. (2010). Development of Pedagogical Technology Integration Content Knowledge in Preparing Mathematics Preservice Teachers: The Role of Instructional Case Analyses and Reflection. Journal of Technology and Teacher Education, 18(4), 645-669. Chesapeake, VA: Society for Information Technology \& Teacher Education. Retrieved February 17, 2017 from https://www.learntechlib.org/p/30334.

[12] Koehler, M., Mishra, P., and Cain, W. (2013). What is Technological Pedagogical Content Knowledge (TPACK)? Journal of Education, 193(3), 13-19. Retrieved from:http://journals.sagepub.com/doi/abs/10.1177/002205741319300303\#articleCitationDownloadC o ntainer

[13] Koehler, M., \& Mishra, P. (2009). What is technological pedagogical content knowledge (TPACK)?. Contemporary issues in technology and teacher education, 9(1), 60-70.

[14] Joo, Y. J., Park, S., \& Lim, E. (2018). Factors Influencing Preservice Teachers' Intention to Use Technology: TPACK, Teacher Self-efficacy, and Technology Acceptance Model. Journal of Educational Technology \& Society, 21(3), 48-59.

[15] Leeman, J. (2013). Guiding Pre-service Teachers Toward Technology Supported LearnerCentered Instruction: Using the TPACK Literature to Inform Teacher Educator Pedagogy. In R. McBride \& M. Searson (Eds.), Proceedings of Society for Information Technology \& Teacher Education International Conference 2013 (4983-4988). Chesapeake, VA: Association for the Advancement of Computing in Education (AACE). Retrieved February 22, 2017 from https://www.learntechlib.org/p/48918.

[16] Lee, Y., \& Lee, J. (2014). Enhancing pre-service teachers' self-efficacy beliefs for technology integration through lesson planning practice. Computers \& Education,73, 121-128. doi:10.1016/j.compedu.2014.01.001 
International Journal on Integrating Technology in Education (IJITE) Vol.8, No.3, September 2019

[17] Lunenberg, Mieke\& Korthagen, Fred \&Swennen, Anja. (2007). The teacher educator as a role model. Teaching and Teacher Education. 586-601. 10.1016/j.tate.2006.11.001.

[18] Mouza, C. and Karchmer-Klein, R. (2013). Promoting and assessing pre-service teachers' technological pedagogical content knowledge (TPACK) in the context of case development. Journal of Educational Computing Research, 48(2), 127-152. Retrieved from: file:///Users/Amy/Downloads/PROMOTINGANDASSESSINGPRE-SERVICE.pdf

[19] Mouza, C., Karchmer-Klein, R. Nandakumar, R., Ozden, S., and Hu, L. (2014). Investigating the impact of an integrated approach to the development of preservice teachers' technological pedagogical content knowledge (TPACK). Elsevier, Computer \& Education, 71(1) 206-221.

[20] Mudzimiri, R. (2012, July). A study of the development of technological pedagogical content knowledge (TPACK) in pre-service secondary mathematics teachers. Retrieved January 22, 2017, from http://scholarworks.montana.edu/xmlui/handle/1/1910

[21] Niess, M. L. (2018). Online Learning Trajectory for Knowledge-Building Communities to Reframe Inservice Teachers' TPACK. In Teacher Training and Professional Development: Concepts, Methodologies, Tools, and Applications (pp. 839-862). IGI Global. International Journal on Integrating Technology in Education (IJITE) Vol.8, No.3, September 201919

[22] Polly, D. (2014). Deepening pre-service teachers' knowledge of technology, pedagogy, and content (TPACK) in an elementary school mathematics methods course. Journal of Computers in Mathematics and Science Teaching, 33(2), 233-250. Chesapeake, VA: Association for the Advancement of Computing in Education (AACE). Retrieved January 27, 2017 from https://www.learntechlib.org/p/43272.

[23] Pugh, K. L., Liu, L., \& Wang, P. (2018, March). Technology Integration in a K-12 Frontier District. In Society for Information Technology \& Teacher Education International Conference (pp. 2117- 2122). Association for the Advancement of Computing in Education (AACE).

[24] Schumer, G. (1999). Mathematics education in Japan. Journal of Curriculum Studies, 31(4), 399-427.

[25] Tondeur, J., van Braak, J., Sang, G., Voogt, J., Fisser, P. \&Ottenbreit-Leftwich, A. (2012). Preparing pre-service teachers to integrate technology in education: A synthesis of qualitative evidence. Computers \& Education, 59(1), 134-144. Elsevier Ltd. Retrieved February 25, 2019 from https://www.learntechlib.org/p/67082/.

[26] Wetzel, K., Buss, R., Foulger, T. S., \& Lindsey, L. (2014). Infusing Educational Technology in Teaching Methods Courses: Successes and Dilemmas. Journal of Digital Learning in Teacher Education,30(3), 89-103. doi:10.1080/21532974.2014.891877

[27] Yigit, M. (2014). A review of the literature: How pre-service mathematics teachers develop their technological, pedagogical, and content knowledge. International Journal of Education in Mathematics, Science and Technology, 2(1), 26-35.

[28] Yurdakul, I. K. (2018). Modeling the relationship between pre-service teachers' TPACK and digital nativity. Educational Technology Research and Development, 66(2), 267-281. 
International Journal on Integrating Technology in Education (IJITE) Vol.8, No.3, September 2019

\section{AUTHORS}

Dr. Barbara Martin is an Assistant Professor of Teaching and Learning in the School of Education, Health, and Human Behavior at Southern Illinois University Edwardsville (SIUE). She teaches in the Elementary and Middle School Programs at SIUE. She has researched, presented and published in the following areas: technology integration, elementary level mathematics instruction, STEM education and

virtual teaching experiences. Finally she researches and woks extensively with the SIUE VirtualProfessional Practice Lab, http://www.siue.edu/virtual-practice-lab/.

Karlee Stapf is a student at Southern Illinois University Edwardsville (SIUE), studying elementary education with an endorsement in Middle School Science. She is a Golden Apple Scholar, teaches in schools-of-need over the summer and serves as a Give 30 Mentor. Karlee as worked closely over the past year with Dr. Martin as an SIUE Undergraduate Researcher. During this research she has closely examined how to successfully integrate technology into math methods courses in the SIUE teacher preparation program.

Additional authors include: Maria Prete, Amy Herpel and Ashley Schaefer 